ARTICLE

\title{
Improving the alkali metal electrode/inorganic solid electrolyte contact via room-temperature ultrasound solid welding
}

\author{
Xinxin Wang (1) ${ }^{1}$, Jingjing Chen (iD ${ }^{2}$, Dajian Wang ${ }^{2} \&$ Zhiyong Mao (iD ${ }^{1 凶}$
}

The combination of alkali metal electrodes and solid-state electrolytes is considered a promising strategy to develop high-energy rechargeable batteries. However, the practical applications of these two components are hindered by the large interfacial resistance and growth of detrimental alkali metal depositions (e.g., dendrites) during cycling originated by the unsatisfactory electrode/solid electrolyte contact. To tackle these issues, we propose a room temperature ultrasound solid welding strategy to improve the contact between $\mathrm{Na}$ metal and $\mathrm{Na}_{3} \mathrm{Zr}_{2} \mathrm{Si}_{2} \mathrm{PO}_{12}$ (NZSP) inorganic solid electrolyte. Symmetrical Na|NZSP | Na cells assembled via ultrasonic welding show stable $\mathrm{Na}$ plating/stripping behavior at a current density of $0.2 \mathrm{~mA} \mathrm{~cm}^{-2}$ and a higher critical current density (i.e., $0.6 \mathrm{~mA} \mathrm{~cm}^{-2}$ ) and lower interfacial impedance than the symmetric cells assembled without the ultrasonic welding strategy. The beneficial effect of the ultrasound welding is also demonstrated in Na|NZSP | $\mathrm{Na}_{3} \mathrm{~V}_{2}\left(\mathrm{PO}_{4}\right)_{3}$ full coin cell configuration where 900 cycles at $0.1 \mathrm{~mA} \mathrm{~cm}{ }^{-2}$ with a capacity retention of almost $90 \%$ can be achieved at room temperature.

\footnotetext{
${ }^{1}$ Tianjin Key Laboratory for Photoelectric Materials and Devices, School of Materials Science and Engineering, Tianjin University of Technology, Tianjin 300384, P. R. China. ${ }^{2}$ Key Laboratory of Display Materials and Photoelectric Devices, Tianjin University of Technology, Ministry of Education, Tianjin 300384, P. R. China. 凶email: mzhy1984@163.com
} 
C ommercial lithium ions batteries (LIBs) have promoted the rapid development of electrochemical energy storage technology in the past decades. However, the energy density of LIBs reached a bottleneck and the safety issues of liquid organic electrolyte used in LIBs were denounced ${ }^{1,2}$. Solid-state alkali metal batteries employing solid-state electrolytes are recognized as the next-generation energy storage technology due to their merits in high-energy density and safety performances as well as long-life time $e^{3,4}$. Nevertheless, the practical application of solid-state batteries is hindered seriously by the poor contact between electrodes and solid-state electrolyte as well as the resultant interfacial issues ${ }^{5}$. Such as, the poor contact of interface leads to a huge interface resistance $e^{6,7}$, preventing the effective transport of ions; the uneven deposition/stripping of metal anode at the discontinuous contact interface results in the growth of metal dendrites during the electrochemical cycling process, eventually causing the failure of batteries ${ }^{8,9}$. Among various types of solid-state electrolytes, oxide ceramic electrolytes have been closely concerned in view of their high ion conductivity $\left(10^{-4} \sim 10^{-3} \mathrm{~S} \mathrm{~cm}^{-1}\right)$ and wide voltage window ${ }^{10,11}$. Especially, the good mechanical strength of oxide ceramic electrolytes can effectively alleviate and inhibit the dendritic growth of alkali metal anode ${ }^{12,13}$. However, the problem of poor contact between metal anode and rigid oxide ceramic electrolytes is most prominent among the solid-state batteries involving in various types of solid-state electrolytes.

A series of strategies have been approached to improve the interface contact between metal electrodes and oxide ceramic electrolytes ${ }^{14,15}$. Static pressing was mostly employed to improve the physical contact between the metal anode and solid-state electrolyte to a certain extent, but the improvement effect of interface contact with acceptable interface impedance is limited ${ }^{16}$. Fusion welding with the assistance of heating alkali metals beyond their melting points (sodium: $98^{\circ} \mathrm{C}$, lithium: $180^{\circ} \mathrm{C}$ ) was widely used to improve the interface contact of metals anode with solid electrolyte ${ }^{17}$. However, the wettability of molten metal to oxide ceramic was hindered seriously because of the formation of undesired layer on the surface of ceramic electrolyte ${ }^{18-20}$. Very recently, ultrasonication was employed to aggressively promote the joining of molten $\mathrm{Li}$ with $\mathrm{Li}_{7} \mathrm{La}_{3} \mathrm{Zr}_{2} \mathrm{O}_{12}$ (LLZO) and this technology was referred as ultrasonic-assisted fusion welding method ${ }^{21}$. No matter the traditional fusion welding or the newly exploited ultrasonicassisted fusion welding, heating operation for the formation of molten metals is required. Apparently, the heating operation will complicate the assemble of batteries and is unsuitable for large-scale application. The introduction of an interlayer with lithiophilic /sodiophilic character, exampling with $\mathrm{ZnO}^{22}, \mathrm{Al}_{2} \mathrm{O}_{3}{ }^{5}, \mathrm{Li}_{3} \mathrm{PO}_{4}{ }^{23}$, $\mathrm{TiO}_{2}{ }^{24}, \mathrm{Li}_{3} \mathrm{~N}^{25}$, and others, between alkali metal anode and ceramic electrolyte was recognized as an effective route to promote the interface contact, resulting in the obvious decrease of the interface resistance and improved uniform deposition of the alkali metal. For example, $\mathrm{Lu}$ et al. fabricated a $3 \mathrm{D}$ porous structure $\mathrm{Na}_{3} \mathrm{Zr}_{2} \mathrm{Si}_{2} \mathrm{PO}_{12}$ (NZSP) impregnated with $\mathrm{SnO}_{2}$ on its surface and then filled with molten sodium, and reported the application performances in solidstate sodium metal battery ${ }^{26}$. Miao et al. reported that the $\mathrm{AlF}_{3}$ interlayer between the sodium anode and NZSP electrolyte could induce the uniform deposition and stripping of $\mathrm{Na}^{27}$. Nevertheless, the interlayer with poor adhesion might partially peel off and lead to the interface contact becomes even worse, accompanying with the volume change of electrode and the complex electrochemical process during cycling. Thus, it is urgent to develop promising interface joining technology to fabricate intimate contact interface with atom-level bonding between metal anodes and ceramic electrolytes.

The application of ultrasonic welding has been successfully demonstrated in joining metal and ceramic in the past years ${ }^{28-31}$.
High-frequency ultrasonic vibration energy could be converted into the deformation energy, frictional work and limited temperature rise, leading to the quick diffusion of atoms at the interface and the formation of intimate bonding interface ${ }^{29}$. Especially for the joining of metal and ceramic, ultrasonic friction could quickly break oxide film on metal surface and gas film on ceramic surface, promoting the wettability spreading of metal to ceramic ${ }^{32-34}$.

In this work, room temperature ultrasonic solid welding without heating operation is demonstrated to fabricate an intimate contact interface between sodium metal anode and $\mathrm{Na}_{3} \mathrm{Zr}_{2} \mathrm{Si}_{2} \mathrm{PO}_{12}$ ceramic electrolyte. The resultant interface properties and the boosting application performances in solid-state sodium metal batteries are investigated in detail.

\section{Results}

Characterizations of $\mathrm{Na}_{3} \mathrm{Zr}_{2} \mathrm{Si}_{2} \mathbf{P O}_{12}$ electrolyte. Figure 1a depicted the XRD pattern of the prepared $\mathrm{Na}_{3} \mathrm{Zr}_{2} \mathrm{Si}_{2} \mathrm{PO}_{12}$ ceramic pellets, which could be well indexed as the NASICON-type $\mathrm{Na}_{3} \mathrm{Zr}_{2} \mathrm{Si}_{2} \mathrm{PO}_{12}$ targeted phase (PDF \#84-1200). Two weak peaks positioned at $\sim 28.28^{\circ}$ and $\sim 31.51^{\circ}$ were corresponded to the impurity phase of $\mathrm{ZrO}_{2}$ (PDF \#86-1450). The coexistence of small amount of $\mathrm{ZrO}_{2}$ impurity was a common phenomenon caused by the volatility of $\mathrm{Na}$ and $\mathrm{P}$ during high temperature calcination ${ }^{35-38}$. The Nyquist plots of impedance for the prepared $\mathrm{Na}_{3} \mathrm{Zr}_{2} \mathrm{Si}_{2} \mathrm{PO}_{12}$ sheet at different temperature were shown in Fig. 1b. The impedance spectra of electrolyte consisted of a semicircle at high frequency and a diagonal line at low frequency. The size of semicircle represented the grain boundary resistance, and the intercept of semicircle with $X$-axis was the total resistance of bulk and grain boundary. The ionic conductivity of the obtained electrolyte at room temperature was calculated to be $4.3 \times 10^{-4} \mathrm{~S} \mathrm{~cm}^{-1}$. With the increasing of test temperature, the semicircle representing the grain boundary resistance decreased gradually, indicating that the grain boundary resistance occupied a smaller proportion of the total resistance at high temperature. The activation energy $\left(\mathrm{E}_{\mathrm{a}}\right)$ was determined to be $0.291 \mathrm{eV}$ from the slope of the Arrhenius plot in the form of $\ln$ $(\sigma \mathrm{T})$ versus $1000 / \mathrm{T}$. The top SEM view of the prepared electrolyte was shown in Fig. 1c. It was shown that the crystalline grains of $\mathrm{Na}_{3} \mathrm{Zr}_{2} \mathrm{Si}_{2} \mathrm{PO}_{12}$ show a cube-like morphology and some gaps existed between grains. In addition, the cross-section SEM image (Fig. 1d) of $\mathrm{Na}_{3} \mathrm{Zr}_{2} \mathrm{Si}_{2} \mathrm{PO}_{12}$ pellet showed that there were voids in the ceramic even though the electrolyte has the acceptable ionic conductivity $\left(4.3 \times 10^{-4} \mathrm{~S} \mathrm{~cm}^{-1}\right.$ at room temperature) and high density (the density of the prepared electrolyte pellets was $3.10 \sim 3.13 \mathrm{~g} \mathrm{~cm}^{-3}$ with a relative density of $\left.\sim 95 \%\right)$.

Fabrication of intimate contact interface by ultrasound welding. Room temperature ultrasound solid welding was employed to fabricate the intimate contact interface between $\mathrm{Na}$ metal anodes and $\mathrm{Na}_{3} \mathrm{Zr}_{2} \mathrm{Si}_{2} \mathrm{PO}_{12}$ (NZSP) electrolytes, as schematically illustrated in Fig. 2. The Na metal foil was placed on the top of $\mathrm{Na}_{3} \mathrm{Zr}_{2} \mathrm{Si}_{2} \mathrm{PO}_{12}$ pellet, then the ultrasonic horn of a household ultrasonic cleaner (photographic picture, power and frequency of the household ultrasonic cleaner was shown in Supplementary Fig. 1) was loaded on the $\mathrm{Na}$ metal foil with ultrasonic vibration for $\sim 25 \mathrm{~s}$ at room temperature $\left(25-27^{\circ} \mathrm{C}\right.$ ) (Supplementary Movie). The fabricated intimate interface between $\mathrm{Na}$ anode and $\mathrm{Na}_{3} \mathrm{Zr}_{2} \mathrm{Si}_{2} \mathrm{PO}_{12}$ electrolyte by ultrasound welding was indexed as $\mathrm{UW}-\mathrm{Na} / \mathrm{Na}_{3} \mathrm{Zr}_{2} \mathrm{Si}_{2} \mathrm{PO}_{12}$. As a comparison, $\mathrm{Na} / \mathrm{Na}_{3} \mathrm{Zr}_{2} \mathrm{Si}_{2} \mathrm{PO}_{12}$ interface without ultrasonic vibration was fabricated by static pressing method (Kejing MSK-160E, China) with a pressure intensity of $\sim 300 \mathrm{~kg}(\sim 26 \mathrm{MPa})$. Supplementary Fig. 2a displayed the digital photographs of the $\mathrm{Na} / \mathrm{Na}_{3} \mathrm{Zr}_{2} \mathrm{Si}_{2} \mathrm{PO}_{12}$, in which $\mathrm{Na}$ metal anode fabricated by static pressing could be scraped off 

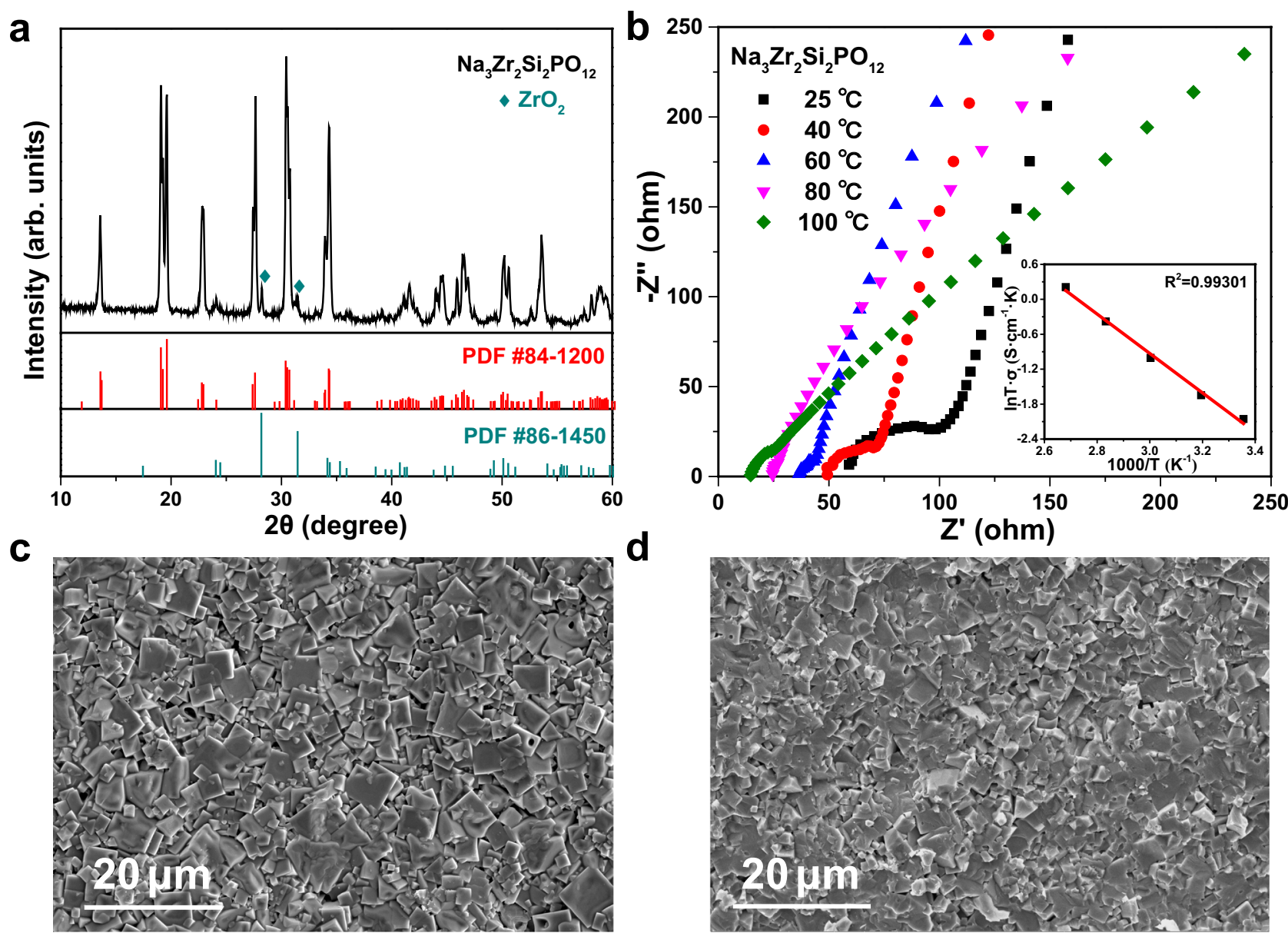

Fig. 1 Physicochemical characterizations of the $\mathbf{N a}_{3} \mathbf{Z r}_{2} \mathbf{S i}_{2} \mathbf{P O}_{12}$ solid electrolyte. a XRD diffraction patterns. $\mathbf{b}$ Nyquist plots and Arrhenius plots of impedance. c Top SEM view. d SEM image of the cross-section.
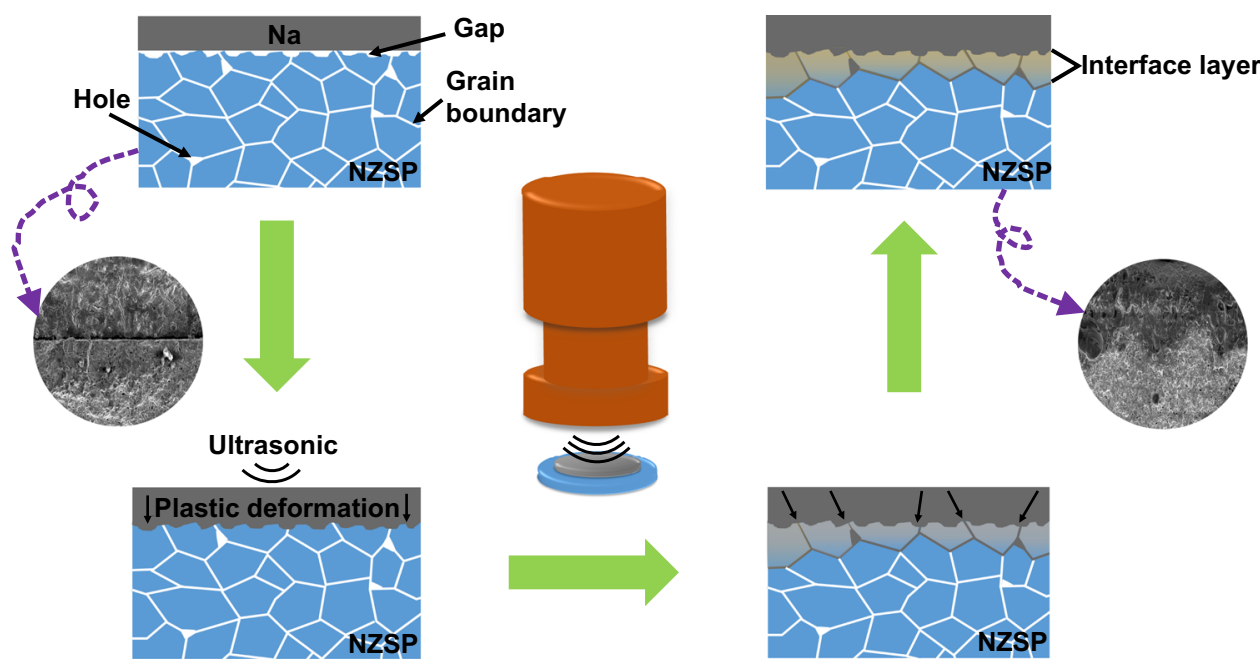

Fig. 2 Schematic illustration of the ultrasound solid welding method. Ultrasonic welding improved the metal Na/NZSP solid electrolyte from poor contact to continuous close contact, and formed a stable interface layer.

easily from the surface of $\mathrm{Na}_{3} \mathrm{Zr}_{2} \mathrm{Si}_{2} \mathrm{PO}_{12}$ pellet, revealing the contact between $\mathrm{Na}$ and electrolyte pellet is poor. On the contrary, $\mathrm{Na}$ electrode still had a large area residue on the surface of $\mathrm{Na}_{3} \mathrm{Zr}_{2} \mathrm{Si}_{2} \mathrm{PO}_{12}$ pellet for the UW-Na/Na $\mathrm{Zr}_{2} \mathrm{Si}_{2} \mathrm{PO}_{12}$ even after scraping with a knife, indicating the intimate contact between $\mathrm{Na}$ foil and $\mathrm{Na}_{3} \mathrm{Zr}_{2} \mathrm{Si}_{2} \mathrm{PO}_{12}$ pellet with the aid of ultrasonic welding (Supplementary Movie and Supplementary Fig. 2b).
Characterizations of interface properties. The contact property of the interface between $\mathrm{Na}$ metal and $\mathrm{Na}_{3} \mathrm{Zr}_{2} \mathrm{Si}_{2} \mathrm{PO}_{12}$ pellet was evaluated by the cross-sectional scanning electron microscopy (SEM) image, as shown in Fig. 3a. The formed interface between $\mathrm{Na}$ metal and $\mathrm{Na}_{3} \mathrm{Zr}_{2} \mathrm{Si}_{2} \mathrm{PO}_{12}$ pellet for UW-Na/ $\mathrm{Na}_{3} \mathrm{Zr}_{2} \mathrm{Si}_{2} \mathrm{PO}_{12}$ was intimate contact without microscopic void defects. In contrast, the $\mathrm{Na} / \mathrm{Na}_{3} \mathrm{Zr}_{2} \mathrm{Si}_{2} \mathrm{PO}_{12}$ interface (Fig. 3b) constructed by static 

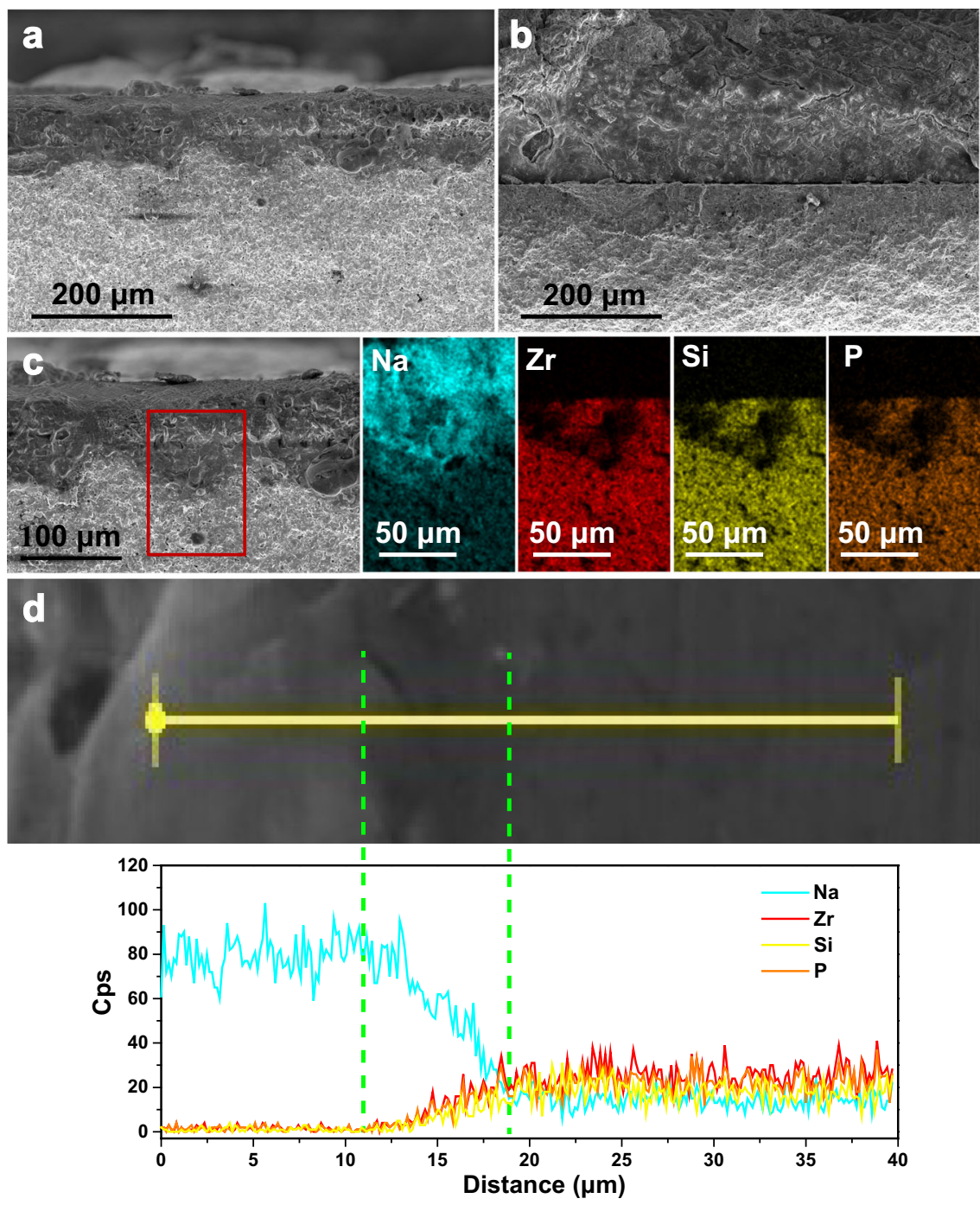

Fig. 3 Ex situ morphological and chemical characterizations of the metal electrode/solid electrolyte interface. a SEM image of the cross-section of UW$\mathrm{Na} / \mathrm{Na}_{3} \mathrm{Zr}_{2} \mathrm{Si}_{2} \mathrm{PO}_{12}$. b SEM image of the cross-section of $\mathrm{Na} / \mathrm{Na}_{3} \mathrm{Zr}_{2} \mathrm{Si}_{2} \mathrm{PO}_{12}$ interfaces. c EDX elemental mappings for UW-Na/Na $\mathrm{Zr} \mathrm{Si}_{2} \mathrm{PO}_{12}$. $\mathbf{d} \mathrm{EDX}$ elemental line scan profile for UW-Na/ $\mathrm{Na}_{3} \mathrm{Zr}_{2} \mathrm{Si}_{2} \mathrm{PO}_{12}$.

pressing without ultrasound welding exhibited obviously gap between $\mathrm{Na}$ anode and $\mathrm{Na}_{3} \mathrm{Zr}_{2} \mathrm{Si}_{2} \mathrm{PO}_{12}$ electrolyte, resulting in large interfacial resistance because of the poor ions transport at the interface ${ }^{39}$. This result verified that ultrasound solid welding was an effective method to construct intimate contact interface between $\mathrm{Na}$ anode and $\mathrm{Na}_{3} \mathrm{Zr}_{2} \mathrm{Si}_{2} \mathrm{PO}_{12}$ electrolyte. The EDX elemental mapping of the selected cross-sectional area for $\mathrm{UW}-\mathrm{Na} / \mathrm{Na}_{3} \mathrm{Zr}_{2}-$ $\mathrm{Si}_{2} \mathrm{PO}_{12}$ interface was reported in Fig. 3c. It was found that the elements of $\mathrm{Zr}$, Si and $\mathrm{P}$ pertaining to $\mathrm{Na}_{3} \mathrm{Zr}_{2} \mathrm{Si}_{2} \mathrm{PO}_{12}$ pellet showed a similar distribution whereas the $\mathrm{Na}$ element has a significant diffusion from the $\mathrm{Na}$ anode into the surface thin layer of $\mathrm{Na}_{3} \mathrm{Zr}_{2} \mathrm{Si}_{2} \mathrm{PO}_{12}$ pellet. This revealed that the Na metal could diffuse into $\mathrm{Na}_{3} \mathrm{Zr}_{2} \mathrm{Si}_{2} \mathrm{PO}_{12}$ pellet along the grain boundaries or the pores of ceramics in view of its rapid plastic deformation under ultrasonic vibration ${ }^{40,41}$. Different from the sodium dendrites that grow along the grain boundary resulted from the poor contact between anode and solid electrolyte, intimate bonding interface with a stable interfacial layer was constructed through interfacial reaction between the diffused $\mathrm{Na}$ metal and $\mathrm{Na}_{3} \mathrm{Zr}_{2} \mathrm{Si}_{2} \mathrm{PO}_{12}$ with the aid of ultrasound. The interfacial reaction mechanism between the $\mathrm{Na}$ and $\mathrm{Na}_{3} \mathrm{Zr}_{2} \mathrm{Si}_{2} \mathrm{PO}_{12}$ induced by ultrasonication was revealed by the $\mathrm{XRD}$ data, as disclosed in Supplementary Fig. 3. Comparing with the pristine $\mathrm{Na}_{3} \mathrm{Zr}_{2} \mathrm{Si}_{2} \mathrm{PO}_{12}$ powder, the ultrasound welding sample of $\mathrm{Na}_{3} \mathrm{Zr}_{2} \mathrm{Si}_{2} \mathrm{PO}_{12}$ powder with sodium metal exhibits some new diffraction peaks: some are originated from the metal sodium but disappears once exposed in air, and others are indexed to be a newly-formed phase of $\mathrm{Na}_{2} \mathrm{SiO}_{3}$, revealing the formation of $\mathrm{Na}_{2} \mathrm{SiO}_{3}$ due to the interfacial reaction. Zhang et al. investigated that $\mathrm{Na}_{3} \mathrm{Zr}_{2} \mathrm{Si}_{2} \mathrm{PO}_{12}$ could be reduced by metal $\mathrm{Na}$ to produce $\mathrm{Na}_{4} \mathrm{SiO}_{4}$ and other reduction products at $0 \mathrm{~V}$, and will further to produce $\mathrm{Na}_{2} \mathrm{SiO}_{3}$ at a higher voltages ${ }^{42}$. In the present work, the newly-formed $\mathrm{Na}_{2} \mathrm{SiO}_{3}$ product was detected during the interfacial reaction under ultrasonication. It was reported that $\mathrm{Na}_{2} \mathrm{SiO}_{3}$ was an ion conductor ${ }^{43}$ and 5 wt. $\% \mathrm{Na}_{2} \mathrm{SiO}_{3}$ presented in $\mathrm{Na}_{3} \mathrm{Zr}_{2}$ $\mathrm{Si}_{2} \mathrm{PO}_{12}$ might result in a high total ionic conductivity of $1.45 \mathrm{mS}$ $\mathrm{cm}^{-1} 44$, indicating that the formation of $\mathrm{Na}_{2} \mathrm{SiO}_{3}$ induced by ultrasonication is beneficial to promote the ions transport in the $\mathrm{UW}-\mathrm{Na} / \mathrm{Na}_{3} \mathrm{Zr}_{2} \mathrm{Si}_{2} \mathrm{PO}_{12}$ interface. The EDX elemental line scan was further used to confirm the successful formation of interface layer for $\mathrm{UW}-\mathrm{Na} / \mathrm{Na}_{3} \mathrm{Zr}_{2} \mathrm{Si}_{2} \mathrm{PO}_{12}$, as depicted in Fig. 3d. An interfacial reaction region with concentration gradient for the involving $\mathrm{Na}, \mathrm{Zr}$, Si and $\mathrm{P}$ elements was observed. To illustrate the generality of the proposed ultrasound solid welding in solid-state metal batteries, intimate contact interfaces between $\mathrm{Li} / \mathrm{Na}$ metal and diversified ceramic electrolytes constructed by ultrasonication were demonstrated in Supplementary Figs. 4-8. The SEM image of 
a

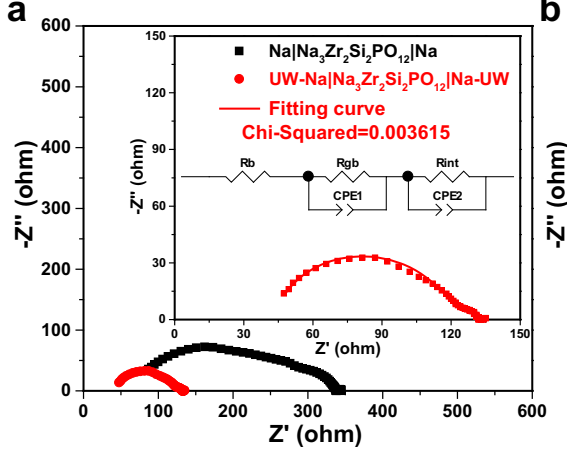

d

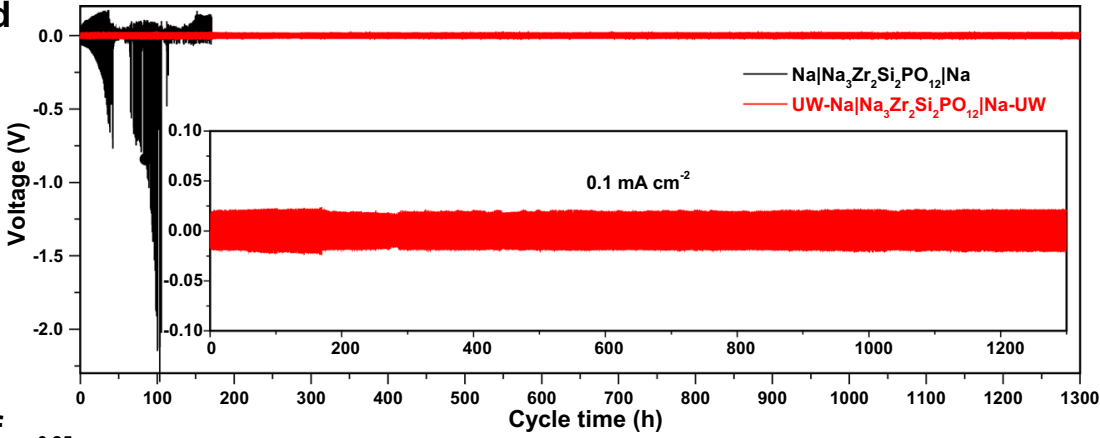

b

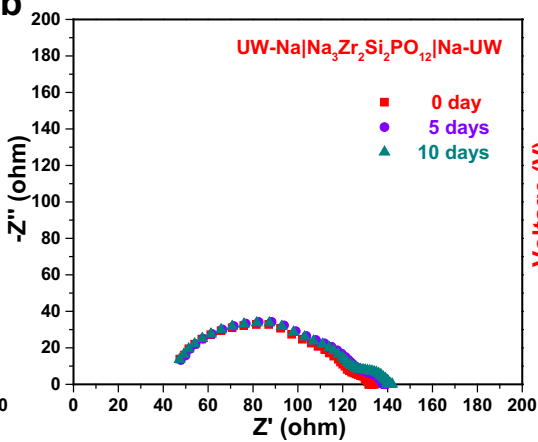

f
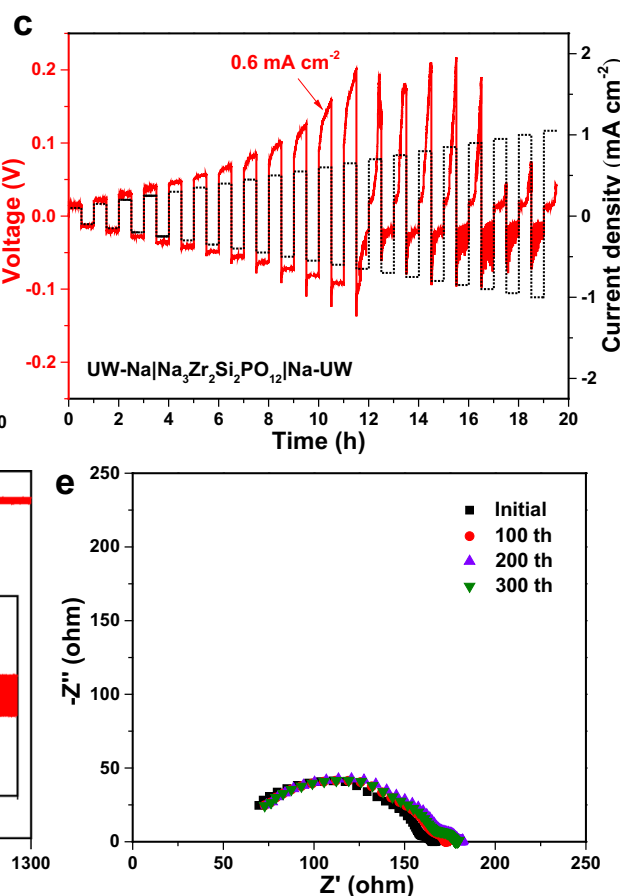

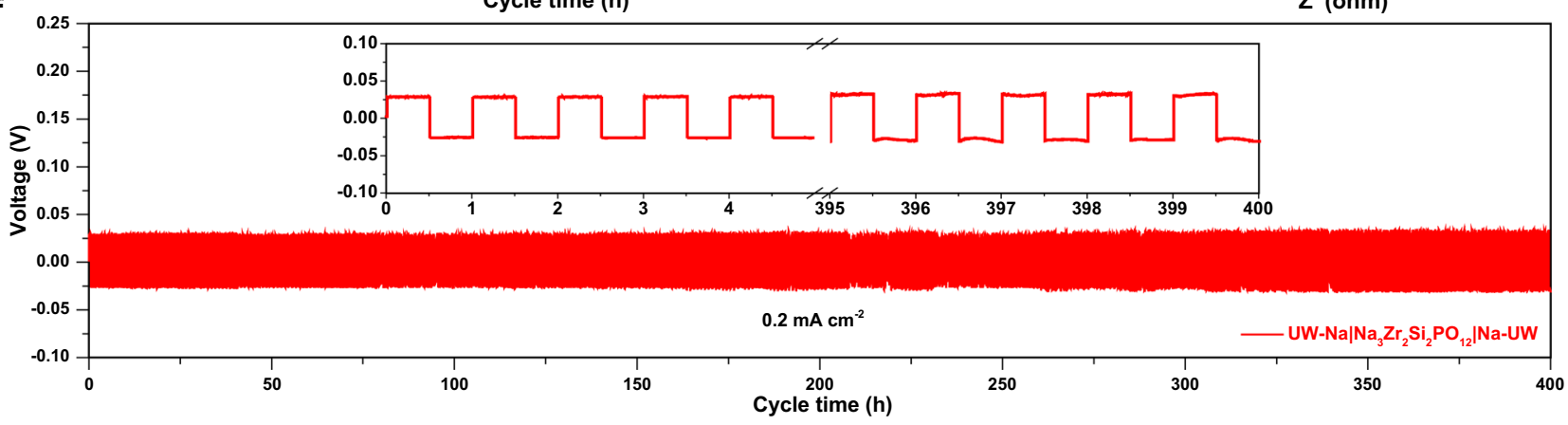

Fig. 4 Electrochemical characterizations of symmetrical $\mathbf{N a}$ metal coin cells with $\mathbf{N a}_{\mathbf{3}} \mathbf{Z r}_{\mathbf{2}} \mathbf{S i}_{\mathbf{2}} \mathbf{P O}_{\mathbf{1 2}}$ solid electrolyte. a The electrochemical impedance spectra for the assembled $\mathrm{Na}\left|\mathrm{Na}_{3} \mathrm{Zr}_{2} \mathrm{Si}_{2} \mathrm{PO}_{12}\right| \mathrm{Na}$ and UW-Na|Na $\mathrm{Zr}_{2} \mathrm{Si}_{2} \mathrm{PO}_{12} \mid \mathrm{Na}-\mathrm{UW}$ symmetrical cells. b Electrochemical impedance spectra during the storage for 10 days of the assembled UW-Na|Na $\mathrm{Zr}_{2} \mathrm{Si}_{2} \mathrm{PO}_{12} \mid \mathrm{Na}-\mathrm{UW}$ symmetrical cell. c Galvanostatic critical current density test. d Galvanostatic cycling of $\mathrm{Na}\left|\mathrm{Na}_{3} \mathrm{Zr}_{2} \mathrm{Si}_{2} \mathrm{PO}_{12}\right| \mathrm{Na}$ and UW-Na $\left|\mathrm{Na}_{3} \mathrm{Zr}_{2} \mathrm{Si}_{2} \mathrm{PO}_{12}\right| \mathrm{Na}-\mathrm{UW}$ symmetrical cells at current density of $0.1 \mathrm{~mA} \mathrm{~cm}{ }^{-2}$. e The electrochemical impedance spectra for the initial and cycled UW-Na| $\mathrm{Na}_{3} \mathrm{Zr}_{2} \mathrm{Si}_{2} \mathrm{PO}_{12} \mid \mathrm{Na}-\mathrm{UW}$ symmetrical cell at current density of $0.1 \mathrm{~mA} \mathrm{~cm}^{-2}$. $\mathbf{f} \mathrm{Galvanostatic} \mathrm{cycling}$ of UW$\mathrm{Na}\left|\mathrm{Na}_{3} \mathrm{Zr}_{2} \mathrm{Si}_{2} \mathrm{PO}_{12}\right| \mathrm{Na}-\mathrm{UW}$ symmetrical cell at current density of $0.2 \mathrm{~mA} \mathrm{~cm}{ }^{-2}$.

the cross-section and the corresponding EDX elemental mappings for $\mathrm{Li} / \mathrm{Na}_{3} \mathrm{Zr}_{2} \mathrm{Si}_{2} \mathrm{PO}_{12}$ (Supplementary Fig. 4), $\mathrm{Na} / \mathrm{Li}_{7} \mathrm{La}_{3} \mathrm{Zr}_{2} \mathrm{O}_{12}$ (Supplementary Fig. 5), Li/Li $\mathrm{La}_{3} \mathrm{Zr}_{2} \mathrm{O}_{12}$ (Supplementary Fig. 6), $\mathrm{Na} / \mathrm{Na}-\beta^{\prime \prime}-\mathrm{Al}_{2} \mathrm{O}_{3}$ (Supplementary Fig. 7) and Li/Na- $\beta "-\mathrm{Al}_{2} \mathrm{O}_{3}$ (Supplementary Fig. 8) interfaces revealed that these interfaces constructed by ultrasonication are intimate without microscopic void defects. Above results verified that ultrasound solid welding is an effective route to construct intimate contact interface between alkali metals anode and ceramic electrolytes, beneficiating to settle the interfacial issues denounced in solid-state alkali metals batteries.

Testing of solid-state cells assembled via ultrasonic welding method. The electrochemical impedance spectra of assembled $\mathrm{Na}\left|\mathrm{Na}_{3} \mathrm{Zr}_{2} \mathrm{Si}_{2} \mathrm{PO}_{12}\right| \mathrm{Na}$ and UW-Na $\left|\mathrm{Na}_{3} \mathrm{Zr}_{2} \mathrm{Si}_{2} \mathrm{PO}_{12}\right| \mathrm{Na}-\mathrm{UW}$ symmetrical cells were measured to evaluate their interface resistance, as displayed in Fig. 4a. Inset showed the fitted data and corresponding equivalent circuit, where $R_{b}, R_{g b}, R_{\text {int }}$ and CPE indicated the bulk resistance, grain boundary resistance, interface resistance and constant phase element, respectively. The left intercept of the arc with $x$-axis at high frequency represents the bulk resistance of $\mathrm{Na}_{3} \mathrm{Zr}_{2} \mathrm{Si}_{2} \mathrm{PO}_{12}$ electrolyte whereas the arc represents to the overlap of grain boundary impedance and interface impedance ${ }^{5}$. The sum of $\mathrm{R}_{\mathrm{b}}$ and $\mathrm{R}_{\mathrm{gb}}$ could be designated as the total resistance of $\mathrm{Na}_{3} \mathrm{Zr}_{2} \mathrm{Si}_{2} \mathrm{PO}_{12}$ electrolyte, which was $\sim 100 \Omega$ measured in the Fig. $1 \mathrm{~b}$. $\mathrm{R}_{\text {int }}$ was determined for the interface resistance on either side of the $\mathrm{Na}$ symmetric cells by subtracting $\mathrm{Na}_{3} \mathrm{Zr}_{2} \mathrm{Si}_{2} \mathrm{PO}_{12}$ electrolyte resistance from UW-Na $\mathrm{Na}_{3} \mathrm{Zr}_{2} \mathrm{Si}_{2} \mathrm{PO}_{12} \mid \mathrm{Na}$-UW or $\mathrm{Na}\left|\mathrm{Na}_{3} \mathrm{Zr}_{2} \mathrm{Si}_{2} \mathrm{PO}_{12}\right| \mathrm{Na}$ cell resistance, dividing by two, and then normalizing to the $\mathrm{Na}$ electrode surface area. The UW-Na $\left|\mathrm{Na}_{3} \mathrm{Zr}_{2} \mathrm{Si}_{2} \mathrm{PO}_{12}\right| \mathrm{Na}-\mathrm{UW}$ cell showed a significantly lower total resistance of $\sim 140 \Omega$ than the $\mathrm{Na} \mid$ $\mathrm{Na}_{3} \mathrm{Zr}_{2} \mathrm{Si}_{2} \mathrm{PO}_{12} \mid \mathrm{Na}$ cell $(\sim 350 \Omega)$ at room temperature. The interfacial resistance of $\mathrm{UW}-\mathrm{Na} / \mathrm{Na}_{3} \mathrm{Zr}_{2} \mathrm{Si}_{2} \mathrm{PO}_{12}$ was evaluated to be $\sim 22.6 \Omega \mathrm{cm}^{2}$, which was lower than that of $\mathrm{Na} / \mathrm{Na}_{3} \mathrm{Zr}_{2} \mathrm{Si}_{2} \mathrm{PO}_{12}$ $\left(141.3 \Omega \mathrm{cm}^{2}\right)$. This significantly lower interfacial resistance for $\mathrm{UW}-\mathrm{Na} / \mathrm{Na}_{3} \mathrm{Zr}_{2} \mathrm{Si}_{2} \mathrm{PO}_{12}$ was dominantly ascribed to the intimate contact and the formed ion conductive $\mathrm{Na}_{2} \mathrm{SiO}_{3}$ induced by ultrasonication. The evolution of electrochemical impedance spectra for the assembled UW-Na $\left|\mathrm{Na}_{3} \mathrm{Zr}_{2} \mathrm{Si}_{2} \mathrm{PO}_{12}\right| \mathrm{Na}-\mathrm{UW}$ symmetrical cell during the storage for 10 days was recorded in Fig. $4 \mathrm{~b}$. There was nearly no change for the impedance spectra 

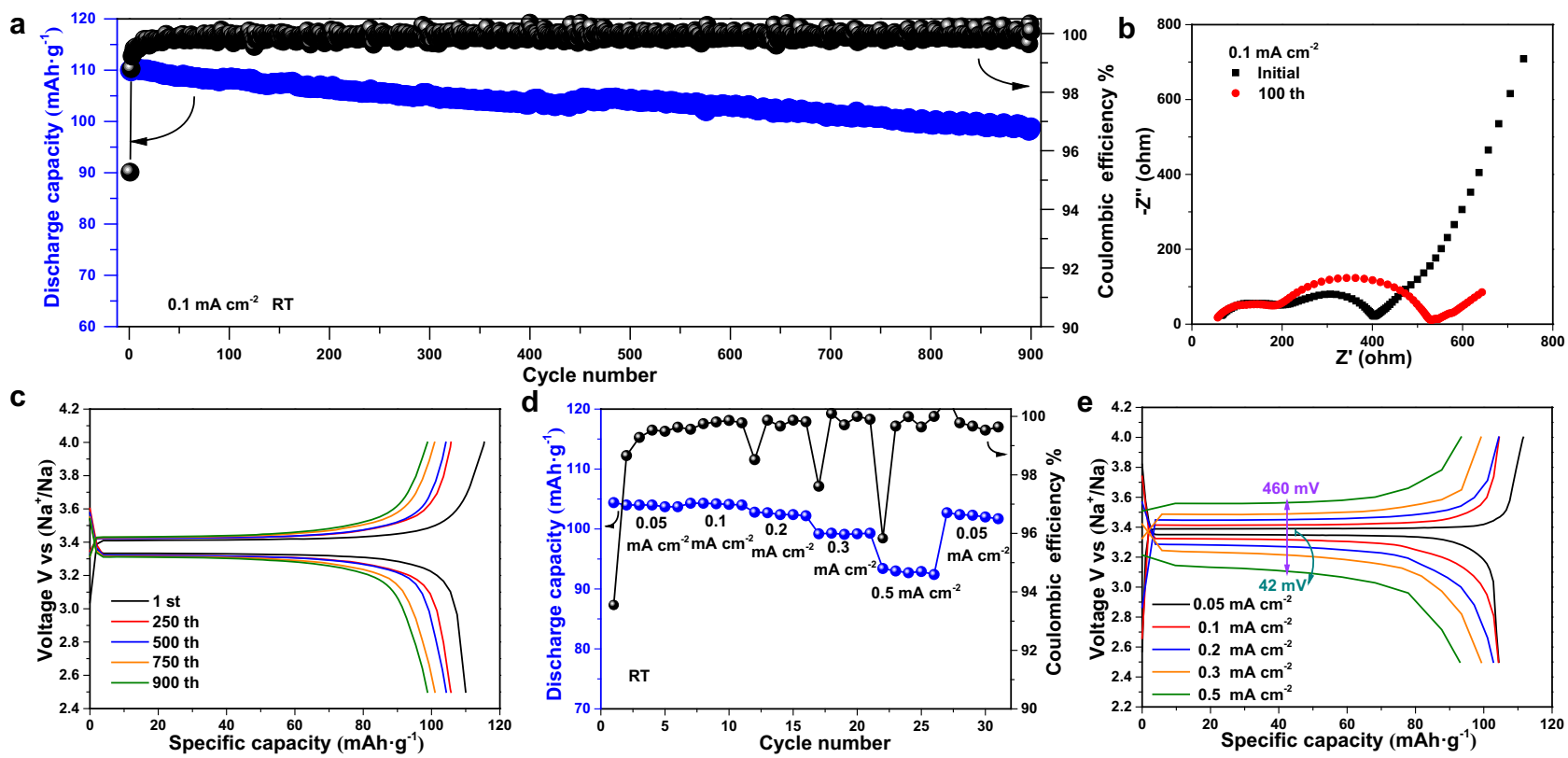
Cycle number
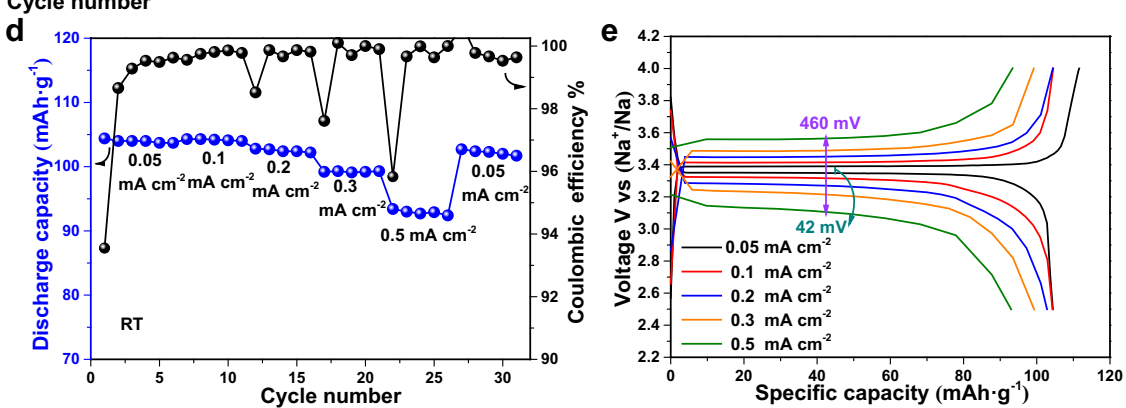

Fig. 5 Electrochemical characterizations of full $\mathbf{N a}$ metal coin cells with $\mathbf{N a}_{\mathbf{3}} \mathbf{Z r}_{\mathbf{2}} \mathbf{S i}_{\mathbf{2}} \mathbf{P O}_{\mathbf{1 2}}$ solid electrolyte. a Cycling performance, $\mathbf{b}$ electrochemical impedance spectra and $\mathbf{c}$ typical charge/discharge curves of the assembled UW-Na $\left|\mathrm{Na}_{3} \mathrm{Zr}_{2} \mathrm{Si}_{2} \mathrm{PO}_{12}\right| \mathrm{Na}_{3} \mathrm{~V}_{2}\left(\mathrm{PO}_{4}\right)_{3}$ solid-state sodium metal cell at $0.1 \mathrm{~mA} \mathrm{~cm}^{-2}$. d The rate performance and e typical charge/discharge curves of the assembled UW-Na $\left|\mathrm{Na}_{3} \mathrm{Zr}_{2} \mathrm{Si}_{2} \mathrm{PO}_{12}\right| \mathrm{Na}_{3} \mathrm{~V}_{2}\left(\mathrm{PO}_{4}\right)_{3}$ cell at various current densities.

with a constant interfacial resistance, indicating the constructed interface by ultrasonication was extremely stable. Galvanostatic critical current density (CCD) was a benchmark to evaluate the electroplating and stripping ability of $\mathrm{Na}$ at the interface under gradually increasing current density ${ }^{45}$. The CCD measurement result for the UW-Na $\left|\mathrm{Na}_{3} \mathrm{Zr}_{2} \mathrm{Si}_{2} \mathrm{PO}_{12}\right| \mathrm{Na}-\mathrm{UW}$ symmetrical cell was presented in Fig. 4c. It was observed that the maximum current density was recorded to be as high as $0.6 \mathrm{~mA} \mathrm{~cm}^{-2}$ with a capacity of $0.6 \mathrm{~mA} \mathrm{~h} \mathrm{~cm}^{-2}$, which was much higher than that of the most reported values $\left(0.07 \sim 0.2 \mathrm{~mA} \mathrm{~cm}^{-2}\right)$ for the $\mathrm{Na}$ $\mathrm{Na}_{3} \mathrm{Zr}_{2} \mathrm{Si}_{2} \mathrm{PO}_{12} \mid \mathrm{Na}$ symmetric cells without any interfacial modification $^{27,42,45}$. Supplementary Fig. 9 displayed the EIS measurements of the correlated total electrochemical resistance during CCD measurements. When the current density was $0.1 \sim 0.35 \mathrm{~mA} \mathrm{~cm}^{-2}$, the recorded impedance spectra was changeless, implying the stability of the $\mathrm{Na} / \mathrm{Na}_{3} \mathrm{Zr}_{2} \mathrm{Si}_{2} \mathrm{PO}_{12}$ interface. With the increase of current density to $0.4 \sim 0.6 \mathrm{~mA} \mathrm{~cm}^{-2}$, the impedance values of the battery were larger than the initial, implying the effective contact of UW-Na/Na $\mathrm{Zr}_{2} \mathrm{Si}_{2} \mathrm{PO}_{12}$ interface was deteriorated due to $\mathrm{Na}$ dissolution and deposition at higher current density. The cycle stability of the assembled cells was evaluated by the Galvanostatic cycling measurements at a current density of $0.1 \mathrm{~mA} \mathrm{~cm}^{-2}$, as demonstrated in Fig. 4d. The UW$\mathrm{Na}\left|\mathrm{Na}_{3} \mathrm{Zr}_{2} \mathrm{Si}_{2} \mathrm{PO}_{12}\right| \mathrm{Na}-\mathrm{UW}$ symmetrical cell exhibited a stable voltage profile with a small overvoltage and without any voltage disturbance during a long cycling time of $1300 \mathrm{~h}$. In contrast, the $\mathrm{Na}\left|\mathrm{Na}_{3} \mathrm{Zr}_{2} \mathrm{Si}_{2} \mathrm{PO}_{12}\right| \mathrm{Na}$ symmetric cell have a large voltage and short-circuited after only $30 \mathrm{~h}$ of cycling, resulting from the poor contact between $\mathrm{Na}$ and $\mathrm{Na}_{3} \mathrm{Zr}_{2} \mathrm{Si}_{2} \mathrm{PO}_{12}$. The nearly unchanged electrochemical impedance spectra (Fig. 4e) for the initial and cycled UW-Na| $\mathrm{Na}_{3} \mathrm{Zr}_{2} \mathrm{Si}_{2} \mathrm{PO}_{12} \mid \mathrm{Na}$-UW symmetrical cell also verified the cycling stability of the ultrasound welding constructed interface. At a higher current density of $0.2 \mathrm{~mA} \mathrm{~cm}^{-2}$, it was also found that the assembled UW-Na $\left|\mathrm{Na}_{3} \mathrm{Zr}_{2} \mathrm{Si}_{2} \mathrm{PO}_{12}\right| \mathrm{Na}-\mathrm{UW}$ symmetrical cell could be cycled firmly with stable voltage and changeless impedance values for a long cycling time (Fig. $4 \mathrm{f}$ and Supplementary Fig. 10). Supplementary Fig. 11a exhibited the cross-section of $\mathrm{UW}-\mathrm{Na} / \mathrm{Na}_{3} \mathrm{Zr}_{2} \mathrm{Si}_{2} \mathrm{PO}_{12}$ recovered from cycled
$\mathrm{Na}$ symmetrical cells at $0.2 \mathrm{~mA} \mathrm{~cm}^{-2}$ after $100 \mathrm{~h}$ cycling. It was observed that the intimate contact interface between $\mathrm{Na}$ and $\mathrm{Na}_{3} \mathrm{Zr}_{2} \mathrm{Si}_{2} \mathrm{PO}_{12}$ could be maintained after cycling. Additionally, the relatively intact cube-like morphology of the electrolyte pellet surface after removing $\mathrm{Na}$ foil with ethanol also confirmed the stability of the UW-Na/Na $\mathrm{Zr}_{2} \mathrm{Si}_{2} \mathrm{PO}_{12}$ interface (Supplementary Fig. 11b).

Supplementary Table 1 provided a detail comparison about the interface resistance and the cycling stability for $\mathrm{Na} \mid \mathrm{Na}_{3} \mathrm{Zr}_{2}$ $\mathrm{Si}_{2} \mathrm{PO}_{12} \mid \mathrm{Na}$ symmetric cells improved with different interface modification routes. It was found that ultrasound solid welding technology facilitates the decrease of interface resistance and improvement of cycling stability comparing with the referring routes, enabling its promising application to settle the interfacial issues of solid-state metal batteries. These results confirmed that the fabricated intimate contact interface induced by ultrasonication not only significantly reduce the interface impedance but also build a stable interface layer to induce the uniform deposition and stripping of $\mathrm{Na}$.

The cycling performance of the assembled UW-Na|Na $\mid \mathrm{Na}_{2}$ $\mathrm{Si}_{2} \mathrm{PO}_{12} \mid \mathrm{Na}_{3} \mathrm{~V}_{2}\left(\mathrm{PO}_{4}\right)_{3}$ sodium metal battery at $0.1 \mathrm{~mA} \mathrm{~cm}^{-2}$ was displayed in Fig. 5a. The first discharge specific capacity was recorded to be $110 \mathrm{mAh} \cdot \mathrm{g}^{-1}$ with a coulombic efficiency of $95.27 \%$. After 900 cycles, the discharge capacity was recorded to be $98.8 \mathrm{mAh} \cdot \mathrm{g}^{-1}$ with a capacity retention ratio of $89.81 \%$ and high coulombic efficiency of $>99.5 \%$, demonstrating the feasibility of full cells based on the highly stable UW-Na/Na $\mathrm{Zr}_{2} \mathrm{Si}_{2} \mathrm{PO}_{12}$ interface. Figure $5 \mathrm{~b}$ showed electrochemical impedance spectra for the initial and cycled UW-Na $\left|\mathrm{Na}_{3} \mathrm{Zr}_{2} \mathrm{Si}_{2} \mathrm{PO}_{12}\right| \mathrm{Na}_{3} \mathrm{~V}_{2}\left(\mathrm{PO}_{4}\right)_{3}$ cell. It was found that the total impedance resistance of the cell shows a slight increase from $400 \Omega$ to $530 \Omega$. This slight increase of total impedance resistance was mainly ascribed to the increasing of cathode interface resistance because the interface resistance of anode was nearly unchangeable. The typical charge/discharge curves of the assembled UW-Na|Na $\mathrm{Nr}_{2} \mathrm{Si}_{2} \mathrm{PO}_{12} \mid \mathrm{Na}_{3} \mathrm{~V}_{2}\left(\mathrm{PO}_{4}\right)_{3}$ cell at $0.1 \mathrm{~mA} \mathrm{~cm}^{-2}$ was displayed in Figure 5c. During 900 times cycling, the overpotential was is stable at $\sim 150 \mathrm{mV}$, which also proved the stability of $\mathrm{UW}-\mathrm{Na} / \mathrm{Na}_{3} \mathrm{Zr}_{2} \mathrm{Si}_{2} \mathrm{PO}_{12}$ interface. Fig. $5 \mathrm{~d}$ 
showed rate performance of the assembled UW-Na $\mid \mathrm{Na}_{3} \mathrm{Zr}_{2}-$ $\mathrm{Si}_{2} \mathrm{PO}_{12} \mid \mathrm{Na}_{3} \mathrm{~V}_{2}\left(\mathrm{PO}_{4}\right)_{3}$ cell when charged/discharged with the current densities ranging from $0.05 \mathrm{~mA} \mathrm{~cm}^{-2}$ to $0.5 \mathrm{~mA} \mathrm{~cm}^{-2}$, which delivered reversible capacity of $104.4 \mathrm{mAh} \cdot \mathrm{g}^{-1}$ at $0.05 \mathrm{~mA}$ $\mathrm{cm}^{-2}, 104.3 \mathrm{mAh} \cdot \mathrm{g}^{-1}$ at $0.1 \mathrm{~mA} \mathrm{~cm}{ }^{-2}, 102.8 \mathrm{mAh} \cdot \mathrm{g}^{-1}$ at $0.2 \mathrm{~mA}$ $\mathrm{cm}^{-2}, 99.3 \mathrm{mAh} \cdot \mathrm{g}^{-1}$ at $0.3 \mathrm{~mA} \mathrm{~cm}{ }^{-2}$ and $93.0 \mathrm{mAh} \cdot \mathrm{g}^{-1}$ at $0.5 \mathrm{~mA} \mathrm{~cm}^{-2}$.

The corresponding typical charge/discharge curves in Fig. 5e validate the good rate performance of the cell under different current densities between $2.5-4 \mathrm{~V}$. In addition, the polarization increased from $42 \mathrm{mV}$ to $460 \mathrm{mV}$ can be observed with the increasing of current density from $0.05 \mathrm{~mA} \mathrm{~cm}^{-2}$ to $0.5 \mathrm{~mA} \mathrm{~cm}{ }^{-2}$, which was due to the slow diffusion of sodium ions under the subsequent high current density ${ }^{46}$. The stable interface constructed by ultrasonication between $\mathrm{Na}$ and $\mathrm{Na}_{3} \mathrm{Zr}_{2} \mathrm{Si}_{2} \mathrm{PO}_{12}$ enables this excellent rate performance ${ }^{26}$. Supplementary Table 2 provides a detail comparison about the reported electrochemical performances of the solid-state sodium metal batteries basing on $\mathrm{Na}_{3} \mathrm{Zr}_{2} \mathrm{Si}_{2} \mathrm{PO}_{12}$ electrolyte. UW-Na $\left|\mathrm{Na}_{3} \mathrm{Zr}_{2} \mathrm{Si}_{2} \mathrm{PO}_{12}\right| \mathrm{Na}_{3} \mathrm{~V}_{2}\left(\mathrm{PO}_{4}\right)_{3}$ cell assembled by the ultrasound solid welding delivers good cycle stability and competitive rate performance.

In summary, room temperature ultrasonic solid welding strategy was demonstrated in this work to construct intimate contact interface between alkali metal anode and oxide solid-state electrolyte. The intimate contact interface with lower interfacial impedance $\left(\sim 22.6 \Omega \mathrm{cm}^{2}\right)$ constructed by ultrasonication enabled the $\mathrm{Na}$ symmetric cell could be stably operated at $0.2 \mathrm{~mA} \mathrm{~cm}^{-2}$ for long cycling time at room temperature. Additionally, the significantly higher critical current density $\left(0.6 \mathrm{~mA} \mathrm{~cm}^{-2}\right)$ illustrated the stable plating/stripping behaviour of $\mathrm{Na}$ metal during cycling. As a result, the assembled UW-Na|Na $\left|\mathrm{Na}_{3} \mathrm{Zr}_{2} \mathrm{Si}_{2} \mathrm{PO}_{12}\right|$ $\mathrm{Na}_{3} \mathrm{~V}_{2}\left(\mathrm{PO}_{4}\right)_{3}$ cell can be well cycled over 900 cycles with a highcapacity retention ratio of $89.81 \%$. This work demonstrated a fast, convenient, low-cost, energy-saving and environmental friendly method to fabricate intimate contact interface between alkali metal anodes and ceramic electrolytes, providing a new gateway to address the interface issues denounced in solid-state metal batteries.

\section{Methods}

Solid-state electrolyte synthesis. $\mathrm{Na}_{3} \mathrm{Zr}_{2} \mathrm{Si}_{2} \mathrm{PO}_{12}$ (NZSP) solid electrolyte was synthesized by the conventional solid-state sintering method. Stoichiometric amount of $\mathrm{Na}_{2} \mathrm{CO}_{3}$ (99.5\%, Aladdin), $\mathrm{ZrO}_{2}$ (99.99\%, Aladdin), $\mathrm{SiO}_{2}$ (99.99\%, Aladdin) and $\mathrm{NH}_{4} \mathrm{H}_{2} \mathrm{PO}_{4}(99 \%$, Aladdin) raw materials were mixed by ball milling with $\mathrm{ZrO}_{2}$ balls $(\Phi 10 \mathrm{~mm})$ at $1200 \mathrm{r} / \mathrm{min}$ for $1 \mathrm{~h}$ in environment atmosphere, and then calcined at $1100{ }^{\circ} \mathrm{C}$ for $12 \mathrm{~h}$ in air atmosphere to obtain precursor. 15 wt. $\%$ quantities of excessive $\mathrm{Na}_{2} \mathrm{CO}_{3}$ and $\mathrm{NH}_{4} \mathrm{H}_{2} \mathrm{PO}_{4}$ were added to compensate the volatilization of $\mathrm{Na}$ and $\mathrm{P}$ elements at high temperature. The obtained precursor was ball-milled at $1200 \mathrm{r} / \mathrm{min}$ for $1 \mathrm{~h}$ and pressed into green pellets at $200 \mathrm{MPa}$, then sintered at $1250{ }^{\circ} \mathrm{C}$ for $6 \mathrm{~h}$ in air atmosphere. The final as-obtained electrolyte pellets were $\sim 800 \mu \mathrm{m}$ in thickness and $\sim 15 \mathrm{~mm}$ in diameter.

\section{Materials characterizations, cells assemble and electrochemical measure-}

ments. The phase structure of the prepared $\mathrm{Na}_{3} \mathrm{Zr}_{2} \mathrm{Si}_{2} \mathrm{PO}_{12}$ pellet was analyzed by $\mathrm{X}$-ray diffraction technology (ARL Equinox 3000, France). The microstructure and elemental composition were characterized by field emission scanning electron microscope equipped with energy dispersive spectrometer (Quanta FEG, America). Ionic conductivity of the prepared $\mathrm{Na}_{3} \mathrm{Zr}_{2} \mathrm{Si}_{2} \mathrm{PO}_{12}$ pellet was evaluated by the electrochemical impedance spectroscopy (EIS) of the $\mathrm{Au}\left|\mathrm{Na}_{3} \mathrm{Zr}_{2} \mathrm{Si}_{2} \mathrm{PO}_{12}\right| \mathrm{Au}$ symmetrical cell operating at a quasi-stationary potential with two-electrode system on an electrochemical workstation $(\mathrm{CHI} 600 \mathrm{E}$, China) in the frequency range from $1 \mathrm{MHz}$ to $1 \mathrm{~Hz}$ at open-circuit voltage, $5 \mathrm{mV}$ amplitude. The recording number of data points was 12 (per decade). UW-Na/Na $\mathrm{Zr}_{2} \mathrm{Si}_{2} \mathrm{PO}_{12} / \mathrm{Na}-\mathrm{UW}$ symmetrical cell was assembled by the proposed ultrasound solid welding for the measurement of interface resistance and cycling stability of the fabricated interface. To evaluate the evolution of interface contact after cycling, the cell was disassembled manually in the glove box by a nipper plier to harvest the solid electrolyte and electrodes for the ex situ SEM measurement transferred by a sealed cans.

The cycle stability of the assembled cells was evaluated by the Galvanostatic cycling measurements at a current density of $0.1 \sim 0.2 \mathrm{~mA} \mathrm{~cm}^{-2}$ at room temperature
(25-27 $\left.{ }^{\circ} \mathrm{C}\right)$. The UW-Na $\left|\mathrm{Na}_{3} \mathrm{Zr}_{2} \mathrm{Si}_{2} \mathrm{PO}_{12}\right| \mathrm{Na}-\mathrm{UW}$ symmetric cells were tested by rate cycling under the initial current density of $0.1 \mathrm{~mA} \mathrm{~cm}^{-2}$ with an increasing step of $0.05 \mathrm{~mA} \mathrm{~cm}^{-2}$ to determine the critical current density (CCD) at room temperature $\left(25-27^{\circ} \mathrm{C}\right)$. For the assemble of UW-Na| $\mathrm{Na}_{3} \mathrm{Zr}_{2} \mathrm{Si}_{2} \mathrm{PO}_{12} \mid \mathrm{Na}_{3} \mathrm{~V}_{2}\left(\mathrm{PO}_{4}\right)_{3}$ solid-state sodium metal batteries, $\mathrm{Na}_{3} \mathrm{~V}_{2}\left(\mathrm{PO}_{4}\right)_{3}$ cathode was prepared by mixing the $\mathrm{Na}_{3} \mathrm{~V}_{2}\left(\mathrm{PO}_{4}\right)_{3} / \mathrm{C}$ (Hubei Energy Technology Co., Ltd, China) with acetylene black carbon and PVDF at a weight ratio of 8:1:1 in the solvent of NMP, then the obtained slurry was casted on $\mathrm{Al}$ foil and dried at $120^{\circ} \mathrm{C}$ in vacuum for $24 \mathrm{~h}$. The load of $\mathrm{Na}_{3} \mathrm{~V}_{2}\left(\mathrm{PO}_{4}\right)_{3} / \mathrm{C}$ in the obtained cathode was $\sim 1 \mathrm{mg} \mathrm{cm}^{-2}$. The thickness of the $\mathrm{Na}_{3} \mathrm{~V}_{2}\left(\mathrm{PO}_{4}\right)_{3} / \mathrm{C}$-based positive electrode was $\sim 0.033 \mathrm{~mm}$ with diameter of $12 \mathrm{~mm}$. CR 2032 coin-type cells were assembled in an argon-filled glovebox $\left(\left[\mathrm{H}_{2} \mathrm{O}\right]<0.1 \mathrm{ppm}\right.$, $\left.\left[\mathrm{O}_{2}\right]<0.1 \mathrm{ppm}\right)$ using $\mathrm{Na}_{3} \mathrm{~V}_{2}\left(\mathrm{PO}_{4}\right)_{3} / \mathrm{C}$ as the cathode, $\mathrm{Na}$ metal as anode and $\mathrm{Na}_{3} \mathrm{Zr}_{2} \mathrm{Si}_{2} \mathrm{PO}_{12}$ as electrolyte respectively. The $\mathrm{Na}$ anode was ultrasound welding on the one side of the $\mathrm{Na}_{3} \mathrm{Zr}_{2} \mathrm{Si}_{2} \mathrm{PO}_{12}$ pellet as described in above. The $\mathrm{Na}$ foil $(99.7 \%$, Aladdin) was prepared with $\sim 12 \mathrm{~mm}$ in diameter and $\sim 120 \mu \mathrm{m}$ in thickness. $7.5 \mu \mathrm{L}$ of liquid electrolyte $\left(1 \mathrm{M} \mathrm{NaClO}_{4}\right.$ in $\mathrm{EC} / \mathrm{DMC}(1: 1)+5 \%$ FEC) was used to wet the interface between cathode and $\mathrm{Na}_{3} \mathrm{Zr}_{2} \mathrm{Si}_{2} \mathrm{PO}_{12}$ sheet. The water content of the electrolyte solution $\leq 50 \mathrm{ppm}$. The assembled $\mathrm{Na}$ metal batteries were galvanostatically charged and discharged in the voltage range of $2.5-4.0 \mathrm{~V}$ vs Na/Na${ }^{+}$at room temperature $\left(25-27^{\circ} \mathrm{C}\right)$ using an automatic battery tester system (Land CT2001A, China). All the electrochemical measurements were performed on a lab bench without temperature control.

\section{Data availability}

The authors declare that all the relevant data are available within the paper and its Supplementary Information file or from the corresponding author upon reasonable request. Source data are provided with this paper.

Received: 10 August 2021; Accepted: 17 November 2021; Published online: 07 December 2021

\section{References}

1. Cheng, X. B., Zhang, R., Zhao, C. Z. \& Zhang, Q. Toward safe lithium metal anode in rechargeable batteries: a review. Chem. Rev. 117, 10403-10473 (2017).

2. Tarascon, J. M. \& Armand, M. Issues and challenges facing rechargeable lithium batteries. Nature 414, 359-367 (2001).

3. Knauth, P. Inorganic solid Li ion conductors: an overview. Solid State Ion. 180, 911-916 (2009).

4. Li, C. L., Zhang, B. \& Fu, Z. W. Physical and electrochemical characterization of amorphous lithium lanthanum titanate solid electrolyte thin-film fabricated by e-beam evaporation. Thin Solid Films 515, 1886-1892 (2006).

5. Han, X. G. et al. Negating interfacial impedance in garnet-based solid-state Li metal batteries. Nat. Mater. 16, 572-579 (2017).

6. Liu, B., Zhang, J. G. \& Xu, W. Advancing lithium metal batteries. Joule 2, 833-845 (2018)

7. Du, M., Liao, K., Lu, Q. \& Shao, Z. Recent advances in the interface engineering of solid-state Li-ion batteries with artificial buffer layers: challenges, materials, construction, and characterization. Energy Environ. Sci. 12, 1780-1804 (2019).

8. Liu, B. Y. et al. 3D lithium metal anodes hosted in asymmetric garnet frameworks toward high energy density batteries. Energy Storage Mater. 14, 376-382 (2018).

9. Fu, K. K. et al. Toward garnet electrolyte-based Li metal batteries: an ultrathin highly effective, artificial solid-state electrolyte/metallic Li interface. Sci. Adv. 3, e1601659 (2017).

10. Masquelier, C. \& Croguennec, L. Polyanionic (Phosphates, Silicates, Sulfates) frameworks as electrode materials for rechargeable $\mathrm{Li}$ (or Na) batteries. Chem. Rev. 113, 6552-6591 (2013)

11. Li, Y. T., Han, J. T., Wang, C. A., Xie, H. \& Goodenough, J. B. Optimizing Li+ conductivity in a garnet framework. J. Mater. Chem. 22, 15357-15361 (2012).

12. Guo, Y. P., Li, H. Q. \& Zhai, T. Y. Reviving lithium-metal anodes for nextgeneration high-energy batteries. Adv. Mater. 29, 1700007 (2017).

13. Luo, W. et al. Transition from superlithiophobicity to superlithiophilicity of garnet solid-state electrolyte. J. Am. Chem. Soc. 138, 12258-12262 (2016).

14. Yang, L. J. et al. Interrelated interfacial issues between a Li7La3Zr2O12-based garnet electrolyte and $\mathrm{Li}$ anode in the solid-state lithium battery: a review. J. Mater. Chem. A 9, 5952-5979 (2021)

15. Oh, J. A. S., He, L. C., Chua, B., Zeng, K. Y. \& Lu, L. Inorganic sodium solidstate electrolyte and interface with sodium metal for room-temperature metal solid-state batteries. Energy Storage Mater. 34, 28-44 (2021).

16. Kasemchainan, J. et al. Critical stripping current leads to dendrite formation on plating in lithium anode solid electrolyte cells. Nat. Mater. 18, 1105-1111 (2019).

17. Zhou, W., Li, Y., Xin, S. \& Goodenough, J. B. Rechargeable sodium all-solidstate battery. ACS Cent. Sci. 3, 52-57 (2017) 
18. Cheng, L. et al. The origin of high electrolyte-electrode interfacial resistances in lithium cells containing garnet type solid electrolytes. Phys. Chem. Chem. Phys. 16, 18294-18300 (2014).

19. Gao, Z. et al. Stabilizing $\mathrm{Na}_{3} \mathrm{Zr}_{2} \mathrm{Si}_{2} \mathrm{PO}_{12} / \mathrm{Na}$ interfacial performance by introducing a clean and Na-deficient surface. Chem. Mater. 32, 3970-3979 (2020).

20. Bay, M. C. et al. Sodium plating from $\mathrm{Na}$-beta"-alumina ceramics at room temperature, paving the way for fast-charging all-solid-state batteries. Adv. Energy Mater. 10, 1902899 (2020).

21. Kitaura H., Hosono E., Zhou H. S. An ultrafast process for the fabrication of a Li metal-inorganic solid electrolyte interface. Energy Environ. Sci. https:// doi.org/10.1039/D1EE00759A (2021).

22. Wang, C. et al. Conformal, nanoscale $\mathrm{ZnO}$ surface modification of garnet-based solid-state electrolyte for lithium metal anodes. Nano Lett. 17, 565-571 (2017).

23. Deng, T. et al. Tuning the anode-electrolyte interface chemistry for garnetbased solid-state Li metal batteries. Adv. Mater. 32, 2000030 (2020).

24. Yang, J. Y. et al. Guided-formation of a favorable interface for stabilizing $\mathrm{Na}$ metal solid-state batteries. J. Mater. Chem. A 8, 7828-7835 (2020).

25. $\mathrm{Xu}, \mathrm{H}$. et al. $\mathrm{Li}_{3} \mathrm{~N}$-modified garnet electrolyte for all-solid-state lithium metal batteries operated at $40{ }^{\circ} \mathrm{C}$. Nano Lett. 18, 7414-7418 (2018).

26. Lu, Y. et al. A high-performance monolithic solid-state sodium battery with $\mathrm{Ca}^{2+}$ doped $\mathrm{Na}_{3} \mathrm{Zr}_{2} \mathrm{Si}_{2} \mathrm{PO}_{12}$ electrolyte. Adv. Energy Mater. 9, 1901205 (2019).

27. Miao, $\mathrm{X}$. et al. $\mathrm{AlF}_{3}$-modified anode-electrolyte interface for effective $\mathrm{Na}$ dendrites restriction in NASICON-based solid-state electrolyte. Energy Storage Mater. 30, 170-178 (2020).

28. Chen, X. G. et al. Interfacial structure and formation mechanism of ultrasonicassisted brazed joint of $\mathrm{SiC}$ ceramics with $\mathrm{Al}-12 \mathrm{Si}$ filler metals in air. J. Mater. Sci. Technol. y. 33, 492-498 (2017).

29. Chen, X. G. et al. Microstructure, mechanical properties, and bonding mechanism of ultrasonic-assisted brazed joints of $\mathrm{SiC}$ ceramics with $\mathrm{ZnAlMg}$ filler metals in air. Ceram. Int. 40, 683-689 (2014).

30. Chen, X. G., Yan, J. C., Ren, S. C., Wei, J. H. \& Wang, Q. Ultrasonic-assisted brazing of $\mathrm{SiC}$ ceramic to Ti-6Al-4V alloy using a novel AlSnSiZnMg filler metal. Mater. Lett. 105, 120-123 (2013).

31. Cui, W., Li, S. Q., Yan, J. C., He, J. S. \& Liu, Y. Ultrasonic-assisted brazing of sapphire with high strength $\mathrm{Al}-4.5 \mathrm{Cu}-1.5 \mathrm{Mg}$ alloy. Ceram. Int. 41, 8014-8022 (2015).

32. Gorjan, L. et al. Fracture behavior of soldered $\mathrm{Al}_{2} \mathrm{O}_{3}$ ceramic to $\mathrm{A} 356$ aluminum alloy and resistance of the joint to low temperature exposure. Mater. Des. 88, 889-896 (2015).

33. Ji, H. J., Cheng, X. \& Li, M. Y. Ultrafast ultrasonic-assisted joining of bare alpha-alumina ceramics through reaction wetting by aluminum filler in air. $J$. Eur. Ceram. Soc. 36, 4339-4344 (2016).

34. Wu, B. Z., Guo, W. B., He, J. S., Xiu, Z. Y. \& Yan, J. C. Microstructure evolution of $\mathrm{SiC} / \mathrm{SiC}$ joints during ultrasonic-assisted air bonding using a $\mathrm{Sn}$ Zn-Al alloy. Ceram. Int. 44, 1284-1290 (2018).

35. Park, H., Kang, M., Park, Y. C., Jung, K. \& Kang, B. Improving ionic conductivity of Nasicon $\left(\mathrm{Na}_{3} \mathrm{Zr}_{2} \mathrm{Si}_{2} \mathrm{PO}_{12}\right)$ at intermediate temperatures by modifying phase transition behavior. J. Power Sources 399, 329-336 (2018).

36. Ruan, Y. L. et al. Improved structural stability and ionic conductivity of $\mathrm{Na}_{3} \mathrm{Zr}_{2} \mathrm{Si}_{2} \mathrm{PO}_{12}$ solid electrolyte by rare earth metal substitutions. Ceram. Int. 43, 7810-7815 (2017).

37. Samiee, $\mathrm{M}$. et al. Divalent-doped $\mathrm{Na}_{3} \mathrm{Zr}_{2} \mathrm{Si}_{2} \mathrm{PO}_{12}$ natrium superionic conductor: Improving the ionic conductivity via simultaneously optimizing the phase and chemistry of the primary and secondary phases. J. Power Sources 347, 229-237 (2017).

38. Park, H., Jung, K., Nezafati, M., Kim, C. S. \& Kang, B. Sodium ion diffusion in Nasicon $\left(\mathrm{Na}_{3} \mathrm{Zr}_{2} \mathrm{Si}_{2} \mathrm{PO}_{12}\right)$ solid electrolytes: effects of excess sodium. ACS Appl. Mater. Interfaces 8, 27814-27824 (2016).

39. Janek, J. \& Zeier, W. G. A solid future for battery development. Nat. Energy 1, 16141 (2016).

40. He, Y. M., Sun, Y., Zhang, J. \& Li, X. D. An analysis of deformation mechanism in the $\mathrm{Si} 3 \mathrm{~N} 4-\mathrm{AgCuTi}+\mathrm{SiCp}-\mathrm{Si}_{3} \mathrm{~N}_{4}$ joints by digital image correlation. J. Eur. Ceram. Soc. 33, 157-164 (2013).
41. Kozlova, O., Voytovych, R. \& Eustathopoulos, N. Initial stages of wetting of alumina by reactive CuAgTi alloys. Scr. Mater. 65, 13-16 (2011).

42. Zhang, Z. et al. $\mathrm{Na}_{3} \mathrm{Zr}_{2} \mathrm{Si}_{2} \mathrm{PO}_{12}$ : a stable $\mathrm{Na}^{+}$-ion solid electrolyte for solidstate batteries. ACS Appl. Energy Mater. 3, 7427-7437 (2020).

43. $\mathrm{Li}, \mathrm{N}$. et al. Suppressing phase transition and improving electrochemical performances of $\mathrm{O} 3-\mathrm{NaNi}_{1 / 3} \mathrm{Mn}_{1 / 3} \mathrm{Fe}_{1 / 3} \mathrm{O}_{2}$ through ionic conductive $\mathrm{Na}_{2} \mathrm{SiO}_{3}$ coating. J. Power Sources 429, 38-45 (2019).

44. Oh, J. A. S. et al. Composite NASICON $\left(\mathrm{Na}_{3} \mathrm{Zr}_{2} \mathrm{Si}_{2} \mathrm{PO}_{12}\right)$ solid-state electrolyte with enhanced $\mathrm{Na}^{+}$ionic conductivity: effect of liquid phase sintering. ACS Appl. Mater. Interfaces 11, 40125-40133 (2019).

45. Fu, H. et al. Reducing Interfacial Resistance by $\mathrm{Na}-\mathrm{SiO}_{2}$ composite anode for NASICON-based solid-state sodium battery. ACS Mater. Lett. 2, 127-132 (2020).

46. Koerver, R. et al. Capacity fade in solid-state batteries: interphase formation and chemomechanical processes in nickel-rich layered oxide cathodes and lithium thiophosphate solid electrolytes. Chem. Mater. 29, 5574-5582 (2017).

\section{Acknowledgements}

We gratefully acknowledge the financial support by the National Natural Science Foundation of China (no. 51777138 (D.W.)), Natural Science Foundation of Tianjin City (nos. 18JCZDJC99700 (D.W.), 18JCYBJC87400 (Z.M.), and 18JCQNJC73900 (J.C.)).

\section{Author contributions}

Z.M. designed the research. X.W. performed the experiment. J.C. and D.W. analyzed the data and commented on the manuscript.

\section{Competing interests}

The authors declare no competing interests.

\section{Additional information}

Supplementary information The online version contains supplementary material available at https://doi.org/10.1038/s41467-021-27473-4.

Correspondence and requests for materials should be addressed to Zhiyong Mao.

Peer review information Nature Communications thanks the anonymous, reviewer(s) for their contribution to the peer review of this work. Peer reviewer reports are available.

Reprints and permission information is available at http://www.nature.com/reprints

Publisher's note Springer Nature remains neutral with regard to jurisdictional claims in published maps and institutional affiliations.

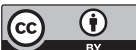

Open Access This article is licensed under a Creative Commons Attribution 4.0 International License, which permits use, sharing, adaptation, distribution and reproduction in any medium or format, as long as you give appropriate credit to the original author(s) and the source, provide a link to the Creative Commons license, and indicate if changes were made. The images or other third party material in this article are included in the article's Creative Commons license, unless indicated otherwise in a credit line to the material. If material is not included in the article's Creative Commons license and your intended use is not permitted by statutory regulation or exceeds the permitted use, you will need to obtain permission directly from the copyright holder. To view a copy of this license, visit http://creativecommons.org/ licenses/by/4.0/.

(C) The Author(s) 2021 